Riwayat draf artikel: Diserahkan 09-07-2021 Diterima 11-08-2021

\section{Penerapan Loose Parts terhadap Kreativitas Anak Usia Dini selama Belajar dari Rumah}

\author{
Siti Rohmatun ${ }^{1}$, Dewi Fitamaya ${ }^{2}$, Erika Lilik Setiyani ${ }^{3}$, \\ Fulka Rohfirsta ${ }^{4}$, Rohmatun Nisa ${ }^{5}$, Muhammad Nofan \\ Zulfahmi ${ }^{6}$ \\ Prodi PG-PAUD FTIK UNISNU Jepara, Indonesia \\ Email korespondesi: Rahma.lail89@gmail.com ${ }^{1}$
}

\begin{abstract}
ABSTRAK: Pada masa pandemi saat ini, pembelajaran tatap muka ditiadakan digantikan dengan kegiatan BDR (Belajar Dari Rumah). Anak akan tertarik dengan kegiatan BDR apabila dikemas dalam bentuk kegiatan yang mengeksplorasi kemampuan kreativitas anak. Pembelajaran berbasis Loose Parts menjadi salah satu media yang dapat berpengaruh dalam program kreativitas anak, serta nantinya anak akan mampu berpikir kritis, analitis, kreatif, dan inovatif. Tujuan penelitian ini untuk mengetahui penerapan Loose Parts terhadap kreativitas anak saat BDR. Metode penelitian yang digunakan yaitu metode kualitatif deskriptif dengan responden peserta didik TK B di TK Pertiwi 12.08 Papasan-Bangsri Jepara yang berjumlah 20 anak. Hasil penelitian menyimpulkan bahwa anak tertarik dalam bermain dengan adanya berbagai benda-benda yang terdapat pada media Loose Parts. Mereka mampu berkreasi dengan media Loose Parts yang telah disediakan oleh orang tua, dan anak juga mampu mengembangkan kreativitas dari hasil proses bermain menggunakan Loose Parts saat BDR.
\end{abstract}

Kata kunci: Anak Usia Dini, BDR, Kreativitas, Loose Parts.

ABSTRACT: During the current pandemic, face-to-face learning is abolished based on BDR (Learning From Home) activities. Children will be interested in BDR activities if they are packaged in the form of activities that explore children's creative abilities. Loose Parts-based learning is one of the media that can influence children's creativity programs, and later children will be able to think critically, analytically, creatively, and innovatively. The purpose of this study was to determine the application of Loose Parts to children's creativity during BDR. The research method used is descriptive qualitative method with the respondents being TK $B$ students at TK Pertiwi 12.08 Papasan-Bangsri Jepara which collected 20 children. The results of the study concluded that children were interested in playing with various objects contained in the Loose Parts media. They are able to be creative with Loose Parts media that has been provided by parents, and children are also able to develop creativity from the results of the playing process using Loose Parts during BDR.

Keywords: BDR, Creativity, early childhood, and Loose Parts

\title{
PENDAHULUAN
}

Indonesia saat ini sedang berupaya mempersiapkan generasi Indonesia emas 2045. Upaya dalam menyiapkan generasi emas dilakukan dalam berbagai hal, misalnya melalui pendidikan. Dibanding dengan negara-negara maju lain, pendidikan di Indonesia masih jauh tertinggal (Nugraheni, 2019). Kualitas pendidikan dapat ditingkatkan untuk membentuk generasi Indonesia yang mampu bersaing dalam segala aspek yang akan terjadi di masa yang akan datang. Peningkatan pendidikan dimulai dari Pendidikan Anak Usia Dini yang merupakan pondasi awal pembentukan karakter anak, maka dari itu pembelajaran pada 
anak usia dini dikemas dalam bentuk bermain seraya belajar. Tahap trial and error menjadi hal yang mendasar dalam setiap kegiatan bermain anak. Anak usia dini memiliki rasa ingin tahu yang tinggi terhadap apa yang ada di lingkungan sekitarnya. Anak senang mencoba hal baru dan banyak bertanya tentang hal apapun yang belum pernah dilakukan, sehingga ketika anak mengalami kegagalan akan terus mencoba dan mengulang sampai apa yang menjadi pertanyaannya dapat terjawab dan ditemukan solusinnya dalam proses pembelajaran.

Permasalahan yang sering dialami dalam kegiatan BDR adalah keterbatasan orang tua dalam melaksanakan pembelajaran dan pengasuhan, seperti kebingungan orang tua dalam menciptakan media belajar di rumah, keterbatasan fasilitas, kurangnya pemahaman orang tua dalam menciptakan lingkungan bermain bagi anak. Permasalahan pembelajaran dalam menghasilkan siswa yang memiliki kompetensi 4c (kreativitas, komunikasi, kolaborasi, berpikir kritis) masih sangat terbatas khususnya di PAUD (Prameswari \& Lestaningrum, 2020). Penerapan Loose Parts dalam pembelajaran anak usia dini menjadi solusi yang efektif pada program BDR. Adapun manfaat dari media Loose Parts yaitu: meningkatkan tingkat kreativitas dan imajinatif anak, meningkatkan sikap kooperatif dan sosialisasi anak, anak lebih aktif secara fisik, mendorong kemampuan komunikasi anak. Loose Parts menjadi energi pembaharu bagi anak dalam bermain. Loose Parts juga menjadi sumber belajar yang diperlukan anak untuk bermain dan dapat menciptakan lingkungan dan pembelajaran yang lebih kreatif, inovatif bagi anak saat bermain. Loose Parts memiliki sifat terbuka sehingga sangat lentur, mudah diubah, ditambahkan, dimodifikasi, dan lain-lain. Loose Parts merupakan barang-barang yang terbuka, yang mudah ditemukan di lingkungan sekitar. Alam kita dipenuhi dengan berbagai macam Loose Parts, seperti ranting, biji pinus, kerang, batu, daun, bunga, dan masih banyak lagi. Loose Parts tersebut dapat dikumpulkan oleh orang tua dan guru dimanapun tanpa mengeluarkan biaya (Nurjanah \& Novita, 2020).

Media pembelajaran untuk anak usia dini beragam dan tidak harus semuanya membeli materi baru dengan biaya yang mahal. Begitu juga dengan media pembelajaran yang dapat digunakan untuk mengembangkan pembelajaran berbasis STEAM. Guru dapat memanfaatkan barang atau bahan yang mudah didapat seperti batu, ranting pohon, biji-bijian, tutup botol bekas, daun kering, jepitan jemuran, dan lain-lain. Bahan lepasan ini disebut bagian lepas. Bagian lepas adalah benda lepas yang dapat digerakkan, dimanipulasi, dan cara penggunaannya ditentukan oleh anak. Bahan lepasan ini sebagai media pembelajaran dapat membuat anak berpikir kreatif dan imajinatif (Wahyuningsih, dkk., 2020). Loose Parts bisa berupa benda- benda ukuran kecil, sedang, ataupun besar. Loose Parts merupakan material bebas dari apa saja yang dapat dimainkan anak, dapat berupa benda-benda alam, benda- benda daur ulang, dan benda- benda buatan pabrik. Contoh benda- benda alam adalah benda- benda yang ditemukan di alam misalnya: tanah, batu, ranting, daun, pasir, kerang, dan lain-lain. Kemudian contoh benda-benda daur ulang misalnya: botol- botol bekas minuman, kardus, bungkus permen, dan lain-lain. Selain itu, 
contoh benda-benda buatan pabrik misalnya: peralatan masak, perkakas rumah tangga, mur, baut, ban, dan lain-lain.

Tujuan pembelajaran dengan Loose Parts adalah anak-anak akan lebih kreatif karena anak bebas berkreasi membongkar pasang bahan Loose Parts yang disediakan sesuai dengan imajinasi mereka. Selain itu anak juga bisa memanfaatkan benda-benda di sekeliling mereka untuk ikut memelihara lingkungan ketika mereka memahami bahwa barang-barang bekas dapat didaur ulang dan dijadikan sebagai bahan untuk bermain dan berkreativitas merakitnya menjadi barang atau hasil karya yang berguna.

Anak akan merasa tertantang untuk dapat menciptakan suatu kreasi baru dengan berbagai bahan yang disediakan, sehingga kegiatan bermain menjadi lebih bermakna. Oleh karena itu, guru atau orang tua harus mampu memberikan stimulus menggunakan bahan dan alat permainan yang beragam sehingga mampu merangsang perkembangan dan kreativitas anak, menjadikan anak tumbuh dan berkembang yang mencintai dan menghargai lingkungan.

\section{METODE PENELITIAN}

Penelitian ini menggunakan pendekatam penelitian kualitatif yaitu penelitian yang bersifat deskriptisf dengan prosedur pengumpulan data melalui observasi dan wawancara. Metode observasi merupakan metode pengumpulan data yang menggunakan pengamatan secara langsung maupun tidak langsung (Riyanto, 2010: 96). Metode wawancara digunakan untuk mendapatkan data tentang kegiatan Belajar Dari Rumah (BDR). Sementara itu, observasi dilakukan dengan menggunakan lembar observasi yang nantinya dapat menggambarkan apa yang terjadi selama pembelajaran termasuk semua proses tindakan, hasil tindakan, dan hambatannya (Furi, dkk., 2019). Metode observasi ini dilakukan untuk mengamati secara langsung anak usia dini di TK B Pertiwi 08.12 Papasan RT 13 RW 03 Papasan Bangsri Jepara dalam pembelajaran BDR.

Metode wawancara peneliti lakukan dengan tanya jawab secara langsung kepada anak, hal ini digunakan untuk memperoleh informasi tentang perkembangan anak dalam pembelajaran Loose Parts. Informan dalam metode wawancara adalah anak-anak dari TK B Pertiwi 08.12 Papasan Bangsri Jepara. Selain itu juga terdapat dokumentasi. Dokumentasi adalah peneliti menyelidiki benda-benda tertulis seperti buku-buku, majalah, dokumen, catatan harian, dan berupa foto (Arikunto, 2006: 158). Teknik analisisnya menggunakan triangulasi data yaitu penggunaan berbagai sumber data sepeti dokumen, arsip, hasil wawancara, hasil observasi yang dijadikan untuk menggali kebenaran informasi.

\section{HASIL DAN PEMBAHASAN}

Ketika Zabidin, Rahmiatin, \& Nasrullah, (2021). Menyebutkan penggunaan Whatsapp dan Youtube untuk mendukung pmebelajaran di masa pandemi, ada berbagai alasan mengapa ruang belajar juga perlu memiliki 
berbagai Loose Part, sehingga lingkungan belajar anak menjadi lingkungan yang interaktif, yang memungkinkan anak dapat bermain secara aktif. Kekhasan Loose Parts adalah karakteristik bendanya yang kaya dengan input sensorial, mulai dari warna, bentuk, tekstur, dan lain-lain. Lingkungan ini akan membantu anak mengenali dunia di sekitarnya. Bermain Loose Parts akan membuat pengalaman sensorial baru bagi anak, sehingga berfungsi untuk menyambungkan sel-sel saraf di otak anak. Otak pada anak usia dini sangat responsif terhadap stimulus sensorial (Siantajani, 2020: 9).

Tersedianya beragam Loose Parts memungkinkan anak dapat menggunakan benda-benda sesuai dengan keinginannya, juga memungkinkan anak memainkannya dengan cara yang berbeda. Loose Parts memberikan kesempatan pada anak untuk menggunakan material lepasan itu menurut ide yang muncul pada anak. Material-material ini dapat berpotensi di transformasi menjadi kreasi-kreasi dan temuan-temuan baru. Ada 7 komponen - komponen Loose Parts yang menjadi media di penelitian ini, yaitu dari bahan alam, plastik, logam, kemasan bekas, kayu dan bambu, benang dan kain, kaca dan keramik. (Damayanti, dkk., 2020).

Loose Parts memiliki manfaat yaitu mengembangkan keterampilan inkuiri. Kemampuan berpikir inkuiri diperlukan anak untuk memperoleh informasi, menganalisa, dan mendorong anak mengembangkan keterampilannya. Pembelajaran terbuka akan membuat anak berfikir, ingin tahu, dan bertanya. Bertanya merupakan pengalaman anak saat berinteraksi dengan orang tua saat bermain Loose Parts. Selain itu Loose Parts juga dapat membantu anak untuk menghubungkan dirinya dengan lingkungannya. Loose Parts dirancang dengan satu tujuan khusus untuk mengembangkan imajinasi, kreativitas, bahasa, dan pengetahuan anak (Wahyuningsih, dkk., 2019).

Peneliti mengobservasi beberapa hal terkait penerapan Loose Parts terhadap kreativitas anak selama belajar dari rumah melalui lembar observasi. Hasil pengamatan melalui lembar observasi saat kegiatan bermain menggunakan Loose Parts dapat dilihat seperti di tabel di bawah ini:

Tabel 1 Lembar Observasi Kreativitas Anak

\begin{tabular}{|c|l|c|c|c|c|c|}
\hline \multirow{2}{*}{ No } & \multicolumn{1}{|c|}{ Aktivitas } & \multicolumn{4}{c|}{ Kriteria Penilaian } & \multirow{2}{*}{ Total } \\
\cline { 3 - 6 } & \multicolumn{1}{|c|}{ BB } & MB & BSH & BSB & 20 \\
\hline 1. & Tertarik pada kegiatan kreatif & & 2 & 10 & 8 & 20 \\
\hline 2. & $\begin{array}{l}\text { Mampu menyampaikan ide } \\
\text { gagasan }\end{array}$ & 1 & 3 & 9 & 7 & 20 \\
\hline 3. & $\begin{array}{l}\text { Keterampilan memecahkan } \\
\text { masalah }\end{array}$ & & 1 & 7 & 12 & 20 \\
\hline 4. & $\begin{array}{l}\text { Mampu menampilkan hasil } \\
\text { karya }\end{array}$ & & 1 & 9 & 10 & 20 \\
\hline 5. & $\begin{array}{l}\text { Memiliki rasa ingin tau yang } \\
\text { tinggi }\end{array}$ & & 2 & 13 & 5 & 20 \\
\hline 6. & Mampu berpikir konstruktivis & & 3 & 8 & 9 & 20 \\
\hline 7. & Memiliki insiatif & & 3 & 10 & 7 & 20 \\
\hline
\end{tabular}


Berdasarkan tabel 1 di atas menunjukkan bahwa 10\% anak berada pada tahap Mulai Berkembang (MB), 50 \% anak telah mencapai Berkembangan Sesuai Harapan (BSH), 40\% anak berada pada tingkat Berkembang Sangat Baik (BSB) pada aktivitas kegiatan kreatif, sedangkan $5 \%$ anak berada pada tingkat Belum Berkembang (BB), 15\% anak Mulai Berkembang (MB) 45\% anak, 35\% anak Berkembangan Sangat Baik (BSB) dalam menyampaikan ide gagasannya. Selanjutnya $5 \%$ anak berada pada pencapaian Mulai Berkembang (MB), 35\% anak berada pada pencapaian Berkembang Sesuai Harapan (BSH), 60\% berada pada tingkat Berkembang Sangat Baik (BSB) dalam keterampilan memecahkan masalah. 5\% anak berada pada tingkat Mulai Berkembang (MB), 45\% anak berada pada tingkat Berkembang Sesuai Harapan (BSH), 50\% anak berada pada tingkat Berkembang Sangat Baik (BSB) saat menampilkan hasil karya. 10\% anak berada pada tingkat Mulai Berkembang (MB), 65\% anak berada pada tingkat Berkembang Sesuai Harapan (BSH), 25\% anak berada pada tingkat Berkembang Sangat Baik (BSB) dalam memiliki rasa ingin tahu yang tinggi. 15\% anak berada pada tingkat Mulai Berkembang (MB), 40\% anak berada pada tingkat Berkembang Sesuai Harapan (BSH), 45\% anak berada pada tingkat Berkembang Sangat Baik (BSB) dalam berpikir konstruktivis. 15\% anak berada pada tingkat Mulai Berkembang (MB), 50\% anak berada pada tingkat Berkembang Sesuai Harapan (BSH), 35\% anak berada pada tingkat Berkembang Sangat Baik (BSB) dalam berinisiatif. Dapat disimpulkan bahwa tingkat pencapaian perkembangan anak pada TK B Pertiwi 08.12 Papasan Bangsri Jepara rata-rata sudah mencapai penilaian Berkembang Sesuai Harapan (BSH).

Hasil wawancara pada anak saat kegiatan bermain menggunakan Loose Parts dapat dilihat seperti di tabel berikut:

Tabel 2 Hasil Percakapan dengan Anak saat Bermain Loose Parts

\begin{tabular}{|c|l|l|l|}
\hline No. & \multicolumn{1}{|c|}{ Pertanyaan } & \multicolumn{1}{|c|}{ Jawaban } & \multicolumn{1}{|c|}{ Analisis } \\
\hline 1 & $\begin{array}{l}\text { Apa yang ingin kamu buat dari } \\
\text { benda-benda itu? }\end{array}$ & $\begin{array}{l}4 \text { anak MB } \\
10 \text { anak BSH } \\
8 \text { anak BSB }\end{array}$ & $\begin{array}{l}\text { Anak membuat rumah } \\
\text { dari kardus-kardus } \\
\text { bekas yang disusun }\end{array}$ \\
\hline 2 & $\begin{array}{l}\text { Apa yang ingin kamu } \\
\text { tambahkan? }\end{array}$ & $\begin{array}{l}12 \text { anak MB } \\
6 \text { anak BSH }\end{array}$ & $\begin{array}{l}\text { Anak menambahkan } \\
\text { batu, daun, dan ranting } \\
\text { sebagai taman depan } \\
\text { rumah }\end{array}$ \\
\hline 3 & $\begin{array}{l}\text { Apa yang kamu lakukan dari } \\
\text { karya yang kamu buat? }\end{array}$ & $\begin{array}{l}6 \text { anak MB } \\
10 \text { anak BSH } \\
4 \text { anak BSB }\end{array}$ & $\begin{array}{l}\text { Anak bermain peran } \\
\text { menjadi anggota } \\
\text { keluarga }\end{array}$ \\
\hline 4 & $\begin{array}{l}\text { Mengapa kamu memilih bahan } \\
\text { itu? }\end{array}$ & $\begin{array}{l}6 \text { anak MB } \\
10 \text { anak BSH } \\
4 \text { anak BSB }\end{array}$ & $\begin{array}{l}\text { Rata-rata anak } \\
\text { menjawab tertarik } \\
\text { dengan bahan yang } \\
\text { disediakan karena } \\
\text { bentuknya unik dan } \\
\text { bervariasi }\end{array}$ \\
\hline
\end{tabular}


Berdasarkan penjelasan tahapan wawancara diatas, bermain Loose Parts dapat mengembangakan pembelajaran kreatif pada anak usia dini. Semakin banyak alat dan bahan diberikan kepada anak, maka semakin kuat motivasi mereka dan semakin kaya pengalaman mereka. Pembelajaran Loose Parts juga dapat mengembangkan pola pikir anak dalam memecahkan masalah, (Lestariningrum \& Intan, 2020), di mana anak lebih kreatif dan bebas bereksplorasi dengan bahan alam seperti batu kerikil, bunga, daun kopi, daun pisang, kardus besar, kardus kecil, botol minuman, lidi kelapa, ranting kering, buah kopi, kayu balok, tutup botol, dan kain perca yang telah disiapkan, anak dapat membuat apa saja sesuai dengan kreativitasnya yang nantinya menghasilkan suatu karya seperti yang terdapat pada gambar dibawah ini dengan memanfaatkan barang-barang bekas yang ada disekitar rumah.

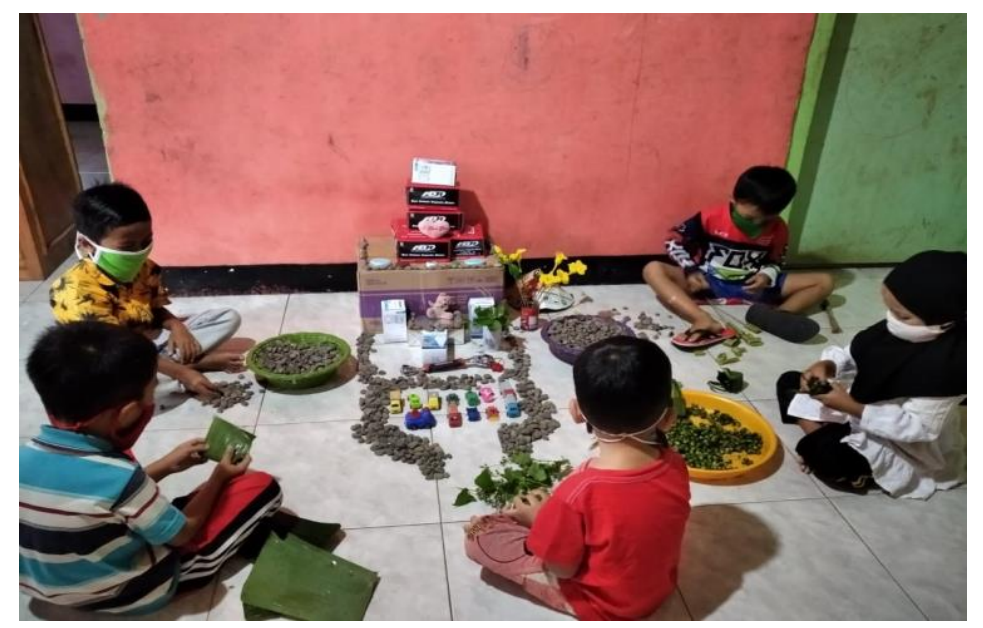

\section{Gambar 1 Anak Bermain Loose Parts dari Bahan Alam dan Bahan Bekas Dikreasikan Bentuk Rumah}

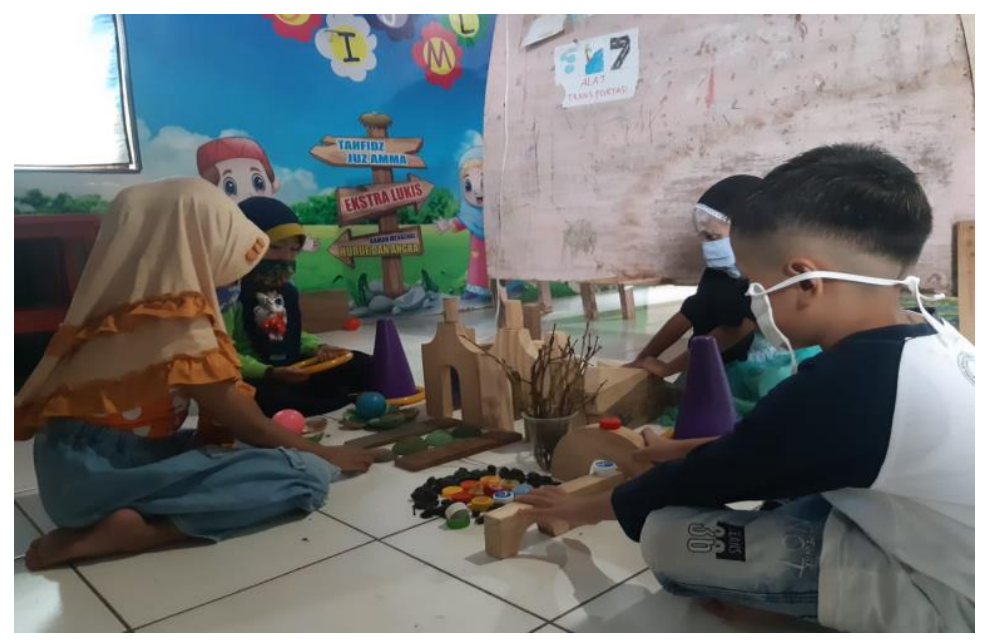

Gambar 2 Anak bermain Loose Parts dari balok, bahan buatan pabrik dan bahan alam berkreasi membentuk sebuah menara kerajaan 


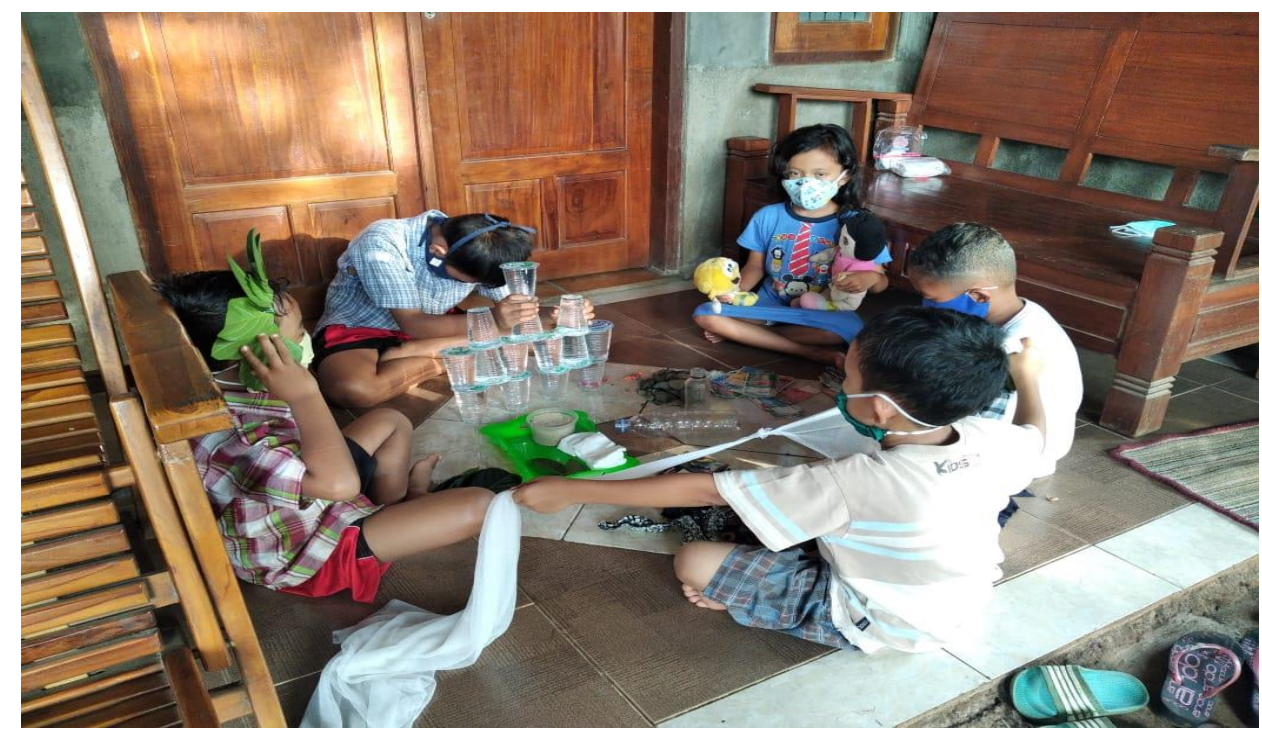

Gambar 3 Anak Bermainan Loose Parts dari Bahan Alam, Bahan Buatan Pabrik, Bahan dari Botol Kemasan.

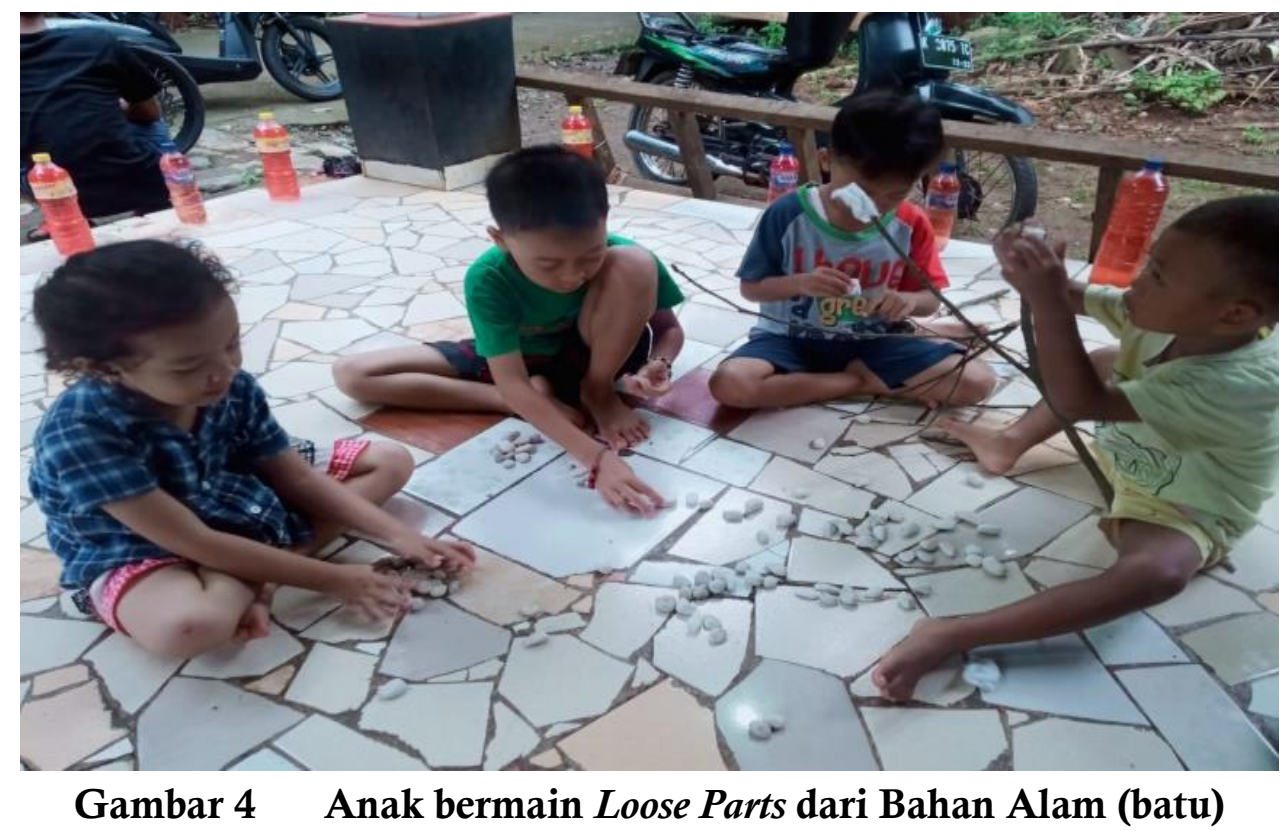

\section{SIMPULAN}

Berdasarkan pembahasan di atas, maka disimpulkan bahwa metode permainan Loose Parts sangat bagus dan efektif untuk merangsang kemampuan bermain seraya belajar karena mereka dapat berimajinasi dan membentuk suatu benda sesuai dengan imajinasinya. Permainan Loose Parts memberikan kebebasan anak untuk bereksplorasi dan mencoba sesuatu yang baru. Kreativitas pada anak dapat berkembang dengan baik jika difasilitasi dengan media pembelajaran yang tepat. Pembelajaran dari rumah dengan media Loose Parts merupakan pembelajaran yang memberikan kebebasan anak untuk berkreasi 
dalam berbagai aktivitas. Pembelajaran ini menggunakan media di sekitar lingkungan dan tidak membutuhkan biaya yang mahal.

\section{UCAPAN TERIMA KASIH}

Terima kasih kepada Bapak Muhammad Nofan Zulfahmi, M.Pd. selaku Dosen Pembimbing dalam pembuatan artikel penelitian yang telah memberikan masukan dan saran. Terimakasih kepada LPPM UNISNU Jepara dan tim editor Journal of Education and Teaching (JET) FKIP-UM Kendari yang telah memfasilitasi publikasi artikel ini.

\section{DAFTAR PUSTAKA}

Arikunto, S. (2006). Metedologi Penelitian. Bina Aksara: Jakarta.

Bambang, R. (2010). Dasar-Dasar Pembelanjaan Perusahaan (4th ed.). BPFE.

Damayanti A., Sriyanti Rahmatunnisa \& Lia Rahmawati. (2020). Peningkatan Kreativitas Berkarya Anak Usia 5-6 Tahun Melalui Pembelajaran Jarak Jauh Berbasis Steam Dengan Media Loose Parts. Jurnal Buah Hati, 7(2), 74-90. https://ejournal.bbg.ac.id/buahhati/article/view/1124.

Furi, A. Z., Harmawati, Denok, M., \& B.A. (2019). Meningkatkan Kemampuan Kognitif melalui Penerapan Metode Eksperimen Menggunakan Media Loose Parts pada Anak Kelompok B. Http://EJournal.Ivet.Ac.Id/Index.Php/Emp/Index, 1(2), 7-19. journal.ivet.ac.id/index.php/emp.

Nurjanah, N. E. (2020). Jurnal audi. Jurnal IImiah Kajian IImu Anak Dan Media Informasi PUD, 1(1), 19-31. https://scholar.google.com/scholar?hl=id\&as sdt=0\%2C5\&q=jurnal+tent ang+STEAM+dan+loose+parts\&oq=\#d=gs qabs\&u=\%23p\%3DMDThokOify EJ.

Prameswari, T., \& Anik Lestariningrum. (2020). Strategi Pembelajaran Berbasis STEAM Dengan Bermain Loose Parts Untuk Pencapaian Keterampilan 4c Pada Anak Usia 4-5 Tahun. Efektor, 7(1), 24-34. https://repository.unpkediri.ac.id/id/eprint/3019.

Siantajani, Y. (2020). Loose Parts. PT Sarang Seratus Aksara.

Sugiyono. (2014). Metode Penelitian Kuantitatif, Kualitatif, dan R\&D. CV. Alfabeta: Bandung.

Wahyuningsih, S., Pudyaningtyas, A. R., Hafidah, R., Syamsuddin, M. M., Nurjanah, N. E., \& Rasmani, U. E. E. (2019). Efek Metode STEAM pada Kreatifitas Anak Usia 5-6 Tahun. Jurnal Obsesi : Jurnal Pendidikan Anak Usia Dini.

Zabidin, D., Rahmiatin, T. ., \& Nasrullah, R. . (2021). The Implementation of Using Whatsapp and Youtube in FLTM Class: Teacher's Perception. Journal of Education and Teaching (JET), 2(1), 10-15. https://doi.org/10.51454/jet.v2i1.28 